\title{
IoT and transparent solar cell based automated green house monitoring system for tomato plant cultivation
}

\author{
Yus Rama Denny $^{1}$, Endi Permata ${ }^{2}$, Adhitya trenggono ${ }^{3}$, Vaka Gustiono $^{4}$ \\ ${ }^{1}$ Department of Physics Education, University of Sultan Ageng Tirtayasa, Serang 42117, Indonesia \\ ${ }^{1}$ Indonesia Center of Excellence for Food Security, University of Sultan Ageng Tirtayasa, Serang, 42435, Indonesia \\ ${ }^{2,4}$ Department of Vocational Electrical Engineering, University of Sultan Ageng Tirtayasa, Serang 42117, Indonesia \\ ${ }^{3}$ Department of Metallurgical Engineering, University of Sultan Ageng Tirtayasa, Banten, Indonesia
}

\begin{tabular}{|c|c|}
\hline Article Info & ABSTRACT \\
\hline Article history: & \multirow{10}{*}{$\begin{array}{l}\text { This study aimed to develop and test the feasibility of a smart greenhouse } \\
\text { prototype media that is used as a planting medium with an automatic } \\
\text { watering system. The method in this study was Research and Development } \\
\text { using the Waterfall model. In order to test the feasibility, the prototype was } \\
\text { validated with material expert validators, media expert, and farmers. The } \\
\text { questionnaire instrument was compiled based on Walker and Hess } \\
\text { instrument. The results of the research found are as follows: the results of } \\
\text { feasibility research by media experts has an average score of } 4.35 \text { with the } \\
\text { category "very feasible", assessment by experts the material has an average } \\
\text { score of } 4.4 \text { with the category "very feasible", and the assessment of the user } \\
\text { has an average score of } 4.06 \text { with "feasible". The purposed controlled system } \\
\text { of smart greenhouse and as a media for farmers was validated. Our results } \\
\text { demonstrated that the smart greenhouse is suitable media to help farmers } \\
\text { cultivating the tomatoes plant. }\end{array}$} \\
\hline Received Apr 17, 2020 & \\
\hline Revised Oct 1, 2020 & \\
\hline Accepted Dec 5, 2020 & \\
\hline Keywords: & \\
\hline Agriculture & \\
\hline Automated green houase & \\
\hline & \\
\hline Tomato plant & \\
\hline & \\
\hline
\end{tabular}

This is an open access article under the CC BY-SA license.

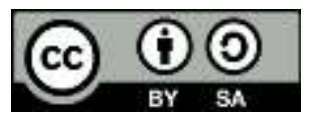

\section{Corresponding Author:}

Yus Rama Denny

Department of Physics Education

University of Sultan Ageng Tirtayasa

Jl. Ciwaru Raya No.25, Cipare, Kec. Serang, Kota Serang, Banten 42117, Indonesia

Email: yusramadenny@untirta.ac.id

\section{INTRODUCTION}

Tomato plant (solanum lycopersicum mill) is a commodity of vegetables that cannot be separated from daily needs as a complementary food. In addition, this plant is rich in vitamins and minerals needed for human growth and health. The high demand for tomatoes in Banten, is not supported by the amount of production of this plant. Based on data from the central statistics agency of Banten Province in 2017, Banten only had a tomato harvest area of 214 hectares which produced 10,168 quintals, but in 2016 the production reached 16789 quintals [1]. It can be concluded that tomato production decreased by 6621 quintals due to the lack of loose soil.

Tomato cultivation requires special attention. It has been reported that tomato is characterized by high water need and it is considered moderatedly sensitive to salinity. Therefore, development of strategies is necessary to enchance efficiency of water use and maintaining the quantity and quality of tomatos production [2-3]. On the other hand, in this case, land and environmental have also factors greatly influence such as temperature, soil moisture, watering, the need for radiation or light intensity and others. In addition, the limited land area, because uncontrolled land has an impact on the balance of the ecosystem due to it causes extreme climate change, therefore the need for tomato cultivation which can overcome this problem. 
Greenhouse is a construction building that functions to avoid and manipulate environmental conditions desired and has complicated procedure since the number of variables involved on it and which are dependent on each other [4-6]. Technological developments in greenhouse are able to adapt, change, and engineer climate namely air temperature, duration of watering, soil Moisture and air circulation [7-8]. The use of greenhouses has been widely used for agriculture in various regions in Indonesia, but the processing in greenhouses is currently still performed manually or semi-automatically which means it still requires human intervention in its management. One of them is the watering process, watering is something that can not be seperated in maintaining and caring so that plants can flourish, but sometimes watering plants is often ignored, so if the water needs needed by tomatoes are not met, it will have a fatal impact on the development of the plant itself. In manual management process, farmers are required to directly observe the plants in the greenhouse. This results in less effective management, longer production processes and high processing costs. Therefore, it requires watering the plants automatically.

Automatic watering system based on internet of think (IoT) that used a microcontroller by using wifi to transmit data that was monitored on an android application. The microcontroller used was NodeMcu which is already integrated with the ESP8266 module as a module for internet connection [9]. In the process of monitoring this system used DHT11 sensor for temperature and humidity monitoring. This tool used a soil moisture sensor which is used as a standard for detecting water content in the soil [10-13]. If the water content conditions in the soil are in accordance with the standards in the program, the automatic watering will start. In this case, automatic control of watering in the form of scheduling and monitoring can be performed wherever farmers are. Implementation of an automatic watering system based on IoT will help farmers in caring for plants and monitoring temperature and humidity, thus providing monitoring and scheduling that can be performed through applications on smartphones connected to the internet [14-15]. With the advancement in technology, everything can be arranged using an automatic control system. The technology still uses electricity, the electricity power needs are very important to maintain the stability of the Greenhouse. But in fact, fossil energy reserves are increasingly depleting, encouraging humans to make renewable and environmentally friendly alternative energy to meet electricity needs. By utilizing sunlight as an alternative power source that is renewable and free of pollution. In fact, in Indonesia renewable energy has not been utilized optimally, as an alternative energy source.

Based on the above problems, this research aimed to make the development of smart greenhouse prototype as a tomato plant cultivation using transparent solar cells as a source of electricity. From the above background, the following problems can be formulated: (1) How is the process of developing the Smart greenhouse prototype as a tomato plant cultivation using a transparent solar cell as an electric source, (2) How is the feasibility of developing a smart greenhouse prototype as a tomato plant cultivation using transparent solar cells as a source of electricity for farmers. The research objectives to be achieved in this research are developing smart greenhouse as tomato plant cultivation using transparent solar cells as a source of electricity and validate the feasibility of smart greenhouse prototype as tomato plant cultivation using transparent solar cells as electricity sources for farmers.

\section{RESEARCH METHOD}

The research method used in this study was research and development (R\&D) with a waterfall development model [16]. The waterfall method consists of five stages, namely requirements definition, system and software design, implementation and unit testing, integration and system testing, operation and maintenance. This research was conducted in June-July, 2019 in the Electrical Engineering Education laboratory and farmer's farmland in the area at Cipocok Village, Serang City, Banten Province. The subjects of this study were 10 farmers. Data collection techniques and research instruments were used to observe, interview, and questionnaires. The questionnaire instrument was compiled based on Walker and Hess instrument [17]. The questionnaire instrument was given to media experts, material experts and farmers as a user. The media expert questionnaire instrument consisted of three aspects namely media design, technical and benefits. The material expert questionnaire consisted of three aspects, namely material and benefits. The user questionnaire instrument consisted of four aspects namely media design, technical, material and benefits.

The questionnaire was validated by means of instruments that have been prepared in consultation with the supervisor or experts in their field (expert judgment) to get a valid instrument assessment. The questionnaire instrument which was declared valid by the expert was then calculated for its reliability using the Cronbach Alpha formula [18]. Data analysis used descriptive analysis. The product was tested for feasibility using a questionnaire assessed by experts and users with a four-choice Likert scale, namely: Strongly Agree, Agree, Disagree and Strongly Disagree. After the data were obtained, then changed the qualitative data into quantitative with an assessment of 1 to 4 . The assessment results were then analyzed and categorized according to the assessment criteria by referring to the quality predicate of the product based on 
the conversion of quantitative to qualitative data, by referring to the quoted formula from Widyoko [19]. The following Table 1 is the conversion of quantitative to qualitative data that was used to interpret the feasibility of the product.

Table 1. Conversion of quantitative to qualitative data [19]

\begin{tabular}{|c|c|c|}
\hline Formula & Mean & Classification \\
\hline $\mathrm{X}>\overline{X_{1}}+1.8 \mathrm{xsbi}$ & $>3.4$ & Strongly Feasible \\
\hline$\overline{X_{1}}+0.6 \mathrm{xsbi}<\mathrm{X} \leq \overline{X_{1}}+1.8 \mathrm{xsbi}$ & $2.8<X \leq 3.4$ & Feasible \\
\hline$\overline{X_{1}}-0.6 \mathrm{xsbi}<\mathrm{X} \leq \overline{X_{1}}+0.6 \mathrm{xsbi}$ & $2.2<\mathrm{X} \leq 2.8$ & Fair \\
\hline$\overline{X_{1}}-1.8 x$ sbi $<\mathrm{X} \leq \overline{X_{1}}-0.6 x s b i$ & $1.6<\mathrm{X} \leq 2.2$ & Not Feasible \\
\hline $\mathrm{X} \leq \overline{X_{1}}-1.8 \mathrm{xsbi}$ & $\leq 1.6$ & Strongly Not Feasible \\
\hline
\end{tabular}

\section{RESULTS AND ANALYSIS}

The aim of this research is to develop a smart greenhouse prototype as a media for cultivating tomatoes plant utilized transparent solar cells as a source of electricity that suitable for tomato farmers in Serang City. In order to design a suitable media, there were 3 stages that we conducted in this study as follows:

\subsection{Learning media development}

The first step to conducte a learning media development, observations and interviews were done with tomato's farmers and the banten agricultural office. The results showed that financial supporting from banten agriculture office was limited for the farmers. This problem will be affected decreasing the production of tomatoes in Banten area. In the farmer point of view, weather and soil condition were constraint in growing tomatoes. According to the other literature, the typcal condition for cultivating tomatoes are temperature range of $24-32{ }^{\circ} \mathrm{C}$, soil humidity of 50-80 RH\%, sunlight of $+400 \mathrm{fc}$ and 500-1500 masl [2-3]. These datas were used to develop hardware and software requirement analysis.

The design of smart green house can be explained on (1) hardware design is a description of the product to be made. The hardware prototype design can be seen in Figures 1(a); (2) Software design, at this stage there were two software namely Arduino IDE 1.8.5 and Blynk. The Arduino IDE 1.8.5 was used to process DHT11 sensor data and soil moisture data was sent to the blynk server via the Internet of Things module. The details information of DHT11 sensor, Arduino, and the Blynk software platform for enviromental monitoring can be found in elsewhere [20-21]. Programming was performed using the blynk format. Data that was sent to blynk can be monitored via android using the blynk application. Blynk is an application used to monitor soil temperature and humidity values; (3) mechanical design is a watering plant monitoring system based on soil moisture. Mechanical design was made with a combination of several components. Mechanical design of smart greenhouse prototype was shown in Figure 1(b); (4) Land design was made with a size of $30 \mathrm{~cm} \mathrm{X} 6 \mathrm{~cm} \mathrm{X} 6 \mathrm{~cm}$ which is adjusted to the size of the prototype. In land design there were three containers of plants (raised beds) where one bed was filled with 10 tomato seeds. The beds were placed vertically facing the solar cell with a distance of $60 \mathrm{~cm}$, the distance between the beds and other beds was $5 \mathrm{~cm}$ so that they are not too close together and can grow well, the position of the beds was closer to the water pipe with a position above the beds with a distance of $30 \mathrm{~cm}$ so that between the pipe and the beds are not too close. Inside the beds, there was a soil moistue sensor with a depth of $5 \mathrm{~cm}$ from the ground surface. The internet of things module was placed outside the planting area. Land design was illustrated in Figure 2(a); (5) Electronic design is a combination of all components in smart greenhouse prototype. Electronic design of the media was presented in Figure 2(b); (6) manual book design was made to facilitate farmers in operating smart greenhouses, (7) the design of the whole tool was a series of whole systems using the internet of things module as a microcontroller. This design that used a DHT11 temperature sensor and a soil moisture sensor will be an indicator of watering the plants. Data obtained from the sensor will be sent via the internet to blynk. The data sent can be monitored on the blynk application that has been installed on Android to run the water pump as a watering system.

After designing hardware and software of smart green house prototype, the next step was an implementation and unit testing of smart green house by utilizing transparent solar cells. There were 2 conditions that conducted during the implementation and unit testing of smart green house. These are condition of greenhouse without watering and with controlled watering. In order to obtain temperature and humidity data in the greenhouse without watering, the temperature testing was carried out from 07.00-17.00 western Indonesian time (WIB). The highest temperature occured at $12.00 \mathrm{WIB}$ with a temperature of $35^{\circ} \mathrm{C}$ and humidity of $35 \%$. The results can be used as a basis data for making temperature and humidity control 
devices in the greenhouse. Temperature and humidity without watering were relatively high, which is between $32-35{ }^{\circ} \mathrm{C}$. This temperature value was not the optimal condition for tomato plant growth because tomato plants require optimal temperatures between $24-32{ }^{\circ} \mathrm{C}$ [22-23], therefore it will not grow maximally. Likewise, the humidity value also affected to the tomato growth. Hence, temperature and humidity need to be controlled. The results of temperature and humidity were shown in Figure 3 and tabulated in Table 2.

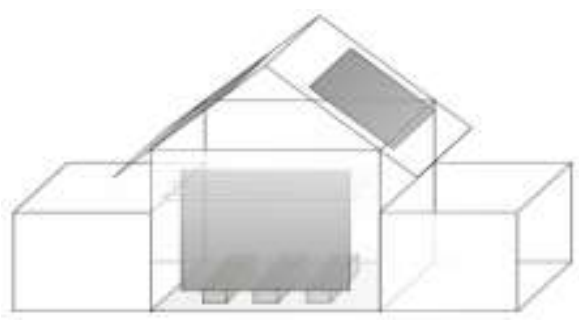

(a)

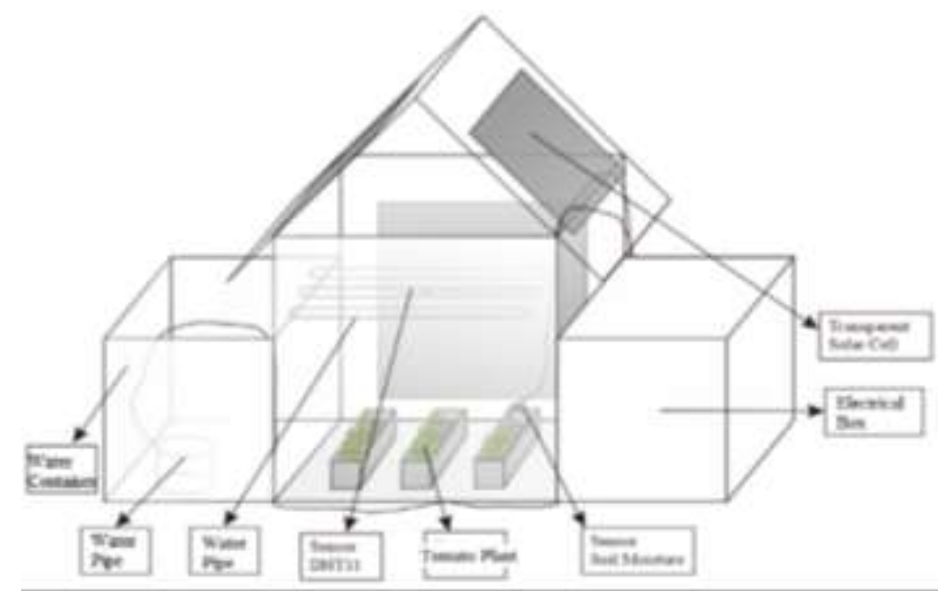

(b)

Figure 1. (a) Hardware prototype design and (b) Mechanical Design of Smart Greenhouse Prototype

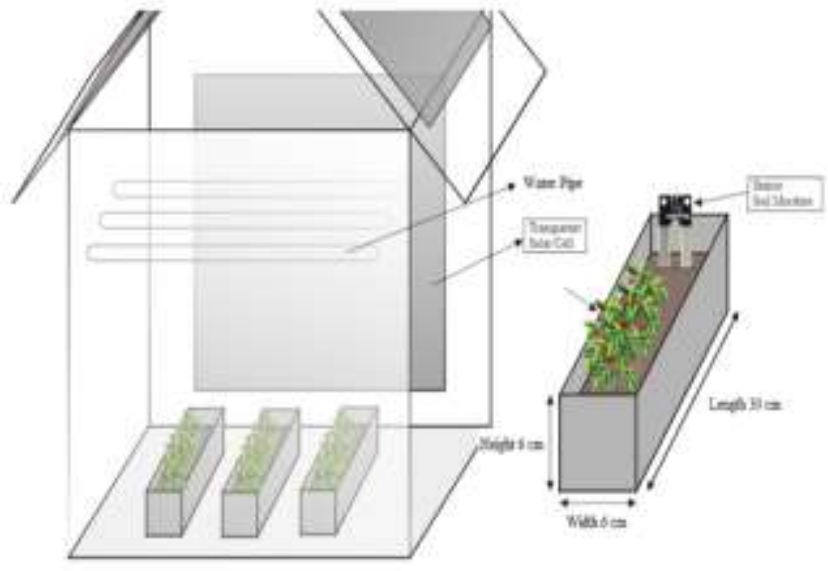

(a)

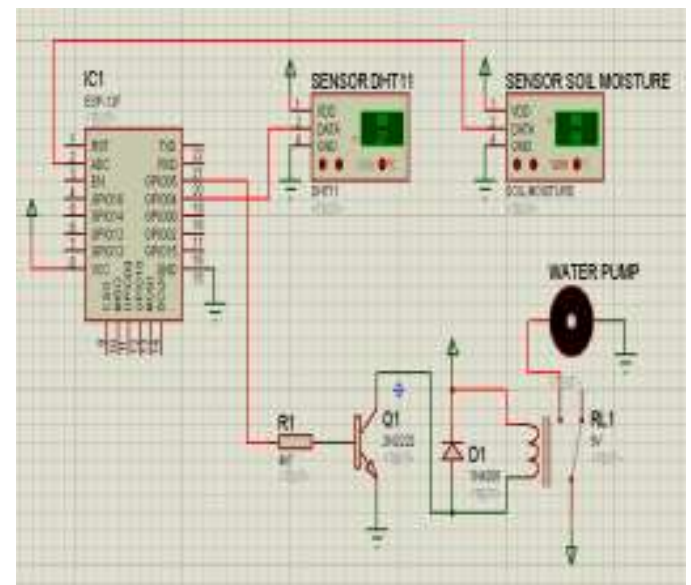

(b)

Figure 2. (a) Land Design and (b) Electronic design of smart greenhouse prototype

Table 2. Smart Greenhouse test for Temperature and Humidity without Watering

\begin{tabular}{cccc}
\hline Time & RH of Soil (\%) & Temperature (C) & RH (\%) \\
\hline 07.00 & 61 & 21 & 50.3 \\
08.00 & 52 & 28 & 51.2 \\
09.00 & 47 & 32 & 48.9 \\
10.00 & 42 & 32 & 50.2 \\
11.00 & 39 & 33 & 43.6 \\
12.00 & 35 & 35 & 43.9 \\
13.00 & 36 & 34 & 44.5 \\
14.00 & 33 & 33 & 44.5 \\
15.00 & 36 & 31 & 46.5 \\
16.00 & 38 & 29 & 47.5 \\
17.00 & 43 & 28 & 48.5 \\
\hline
\end{tabular}




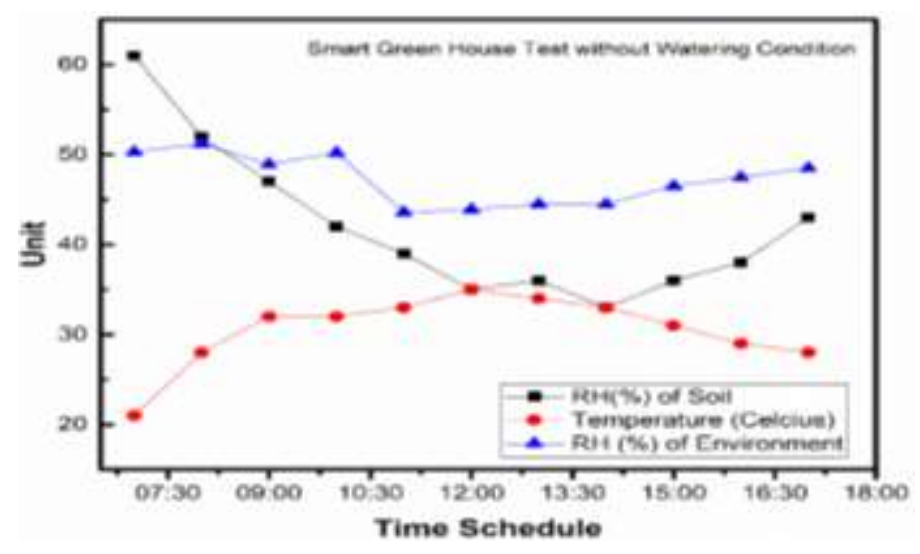

Figure 3. Temperature and Humidity without Watering

The other condition was smart greenhouse with controlled watering. The watering condition was performed in the morning at $07.00 \mathrm{WIB}$. At that time the temperature value was still quite good at $26 \mathrm{oC}$ with $62 \%$ humidity due to controlled watering. However, the temperature inside the greenhouse increased at 11:00 WIB and humidity decreased of $31 \mathrm{oC}$ and $43 \%$ humidity until 16.00 WIB. The temperature inside the Smart Greenhouse increased and humidity decreased of $32 \mathrm{oC}$ and $41 \%$ of humidity at $12.00 \mathrm{WIB}$. This happened because the sun and wind conditions were rather strong. At this time, the humidity sensor gave a signal to the internet of things module therefore the watering occured and the measurement at 01.00 WIB showed a temperature of $28 \mathrm{oC}$ and humidity of $59 \%$. The temperature and humidity sensors were able to control the ups and downs of the temperature and humidity values. The results of temperature and humidity graphs in this test can be seen in Figure 4 and Table 3.

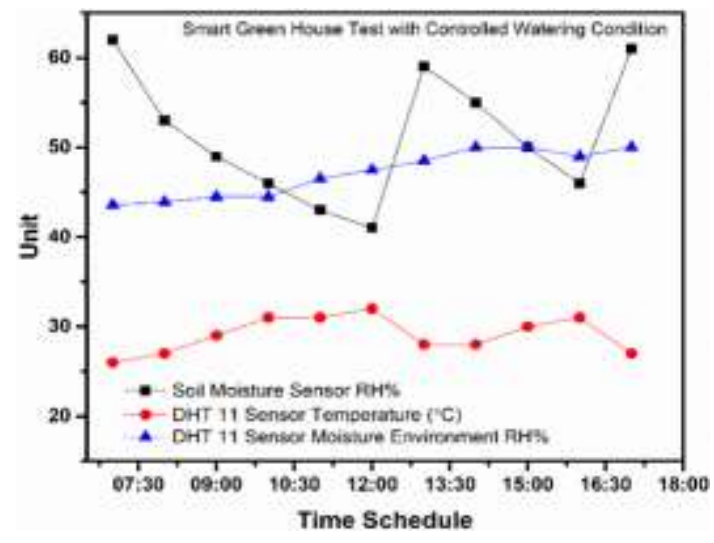

Figure 4. Temperature and humidity sensors data with morning and evening watering
Table 3. Smart Greenhouse test for Temperature and Humidity with Controlled Watering

\begin{tabular}{cccc}
\hline Time & $\begin{array}{c}\text { Soil Moisture } \\
\text { Sensor }\end{array}$ & \multicolumn{2}{c}{ DHT 11 Sensor } \\
\hline & RH $(\%)$ & Temperature $\left({ }^{\circ} \mathrm{C}\right)$ & RH $(\%)$ \\
07.00 & 62 & 26 & 43.6 \\
08.00 & 53 & 27 & 43.9 \\
09.00 & 49 & 29 & 44.5 \\
10.00 & 46 & 31 & 44.5 \\
11.00 & 43 & 31 & 46.5 \\
12.00 & 41 & 32 & 47.5 \\
13.00 & 59 & 28 & 48.5 \\
14.00 & 55 & 28 & 50 \\
15.00 & 50 & 30 & 50 \\
16.00 & 46 & 31 & 49 \\
17.00 & 61 & 27 & 50 \\
\hline
\end{tabular}

The results of the tomato plant height study were carried out for one week in the Electrical Engineering laboratory. This measurement was performed to determine the height of tomato plants. The maximum highest size of tomato plants for a week controlled was $7 \mathrm{~cm}$ in raised beds $\mathrm{A}$ and $\mathrm{B}$. These results have a slightly different with the raised beds $\mathrm{C}$ due to the position of the plant that induced the growing state of the plants. This result was accordance with the others [24-25]. Hence, the position of sunlight affected to the growing state of the tomato's plants. The height measurement results were used as a benchmark for the efficiency of greenhouses in the growth and development of plants so as to produce quality plants. The following graph shows the height of the greenhouse component in Figure 5 and tabulated in Table 4. The results showed that a smart greenhouse can induces the growth of tomatoes plant and suitable for cultivating the plants. 


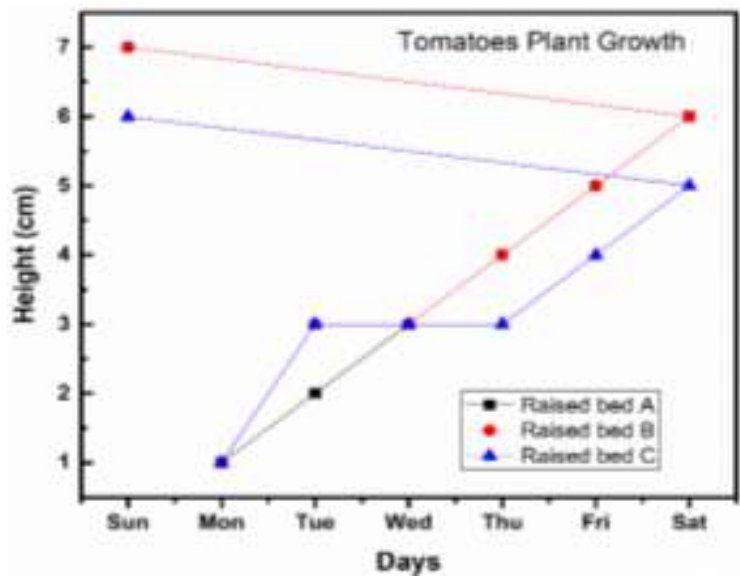

Table 4. Results of Tomato Plant Growth

\begin{tabular}{cccc}
\hline Day & Raised bed & $\begin{array}{c}\text { Height }(\mathrm{cm}) \\
\text { Raised bed } \\
\text { A }\end{array}$ & $\begin{array}{c}\text { Raised bed } \\
\text { C }\end{array}$ \\
\hline Monday & 1 & 1 & 1 \\
Tuesday & 2 & 3 & 3 \\
Wednesday & 3 & 3 & 3 \\
Thursday & 4 & 4 & 3 \\
Friday & 5 & 5 & 4 \\
Saturday & 6 & 6 & 5 \\
Sunday & 7 & 7 & 6 \\
\hline
\end{tabular}

Figure 5. Tomato Plant Growth for every single day

\subsection{Integration and system testing}

(1) Transparent solar cell test. Transparent solar cell test was performed to see it as a source of electricity by charging the battery. There are several factors that influenced the charging battery to run a water pump and internet of things module on a smart greenhouse.

(a) Water pump: The water pump test was carried out by providing a voltage input. Then the output forced the motor to water the plants. Internet of things module : This test was performed by giving a voltage to the sensor of $3.3 \mathrm{~V}$ to $5 \mathrm{~V} \mathrm{DC}$. The internet of things module will receive input from the sensor to control the water pump according to the condition of the Soil Moisture sensor and the DHT11 sensor.

(b) Solar cell: The specification of solar cell was $15 \mathrm{wp}$ which means it has 15 watts peak (when the sun is blazing). Peak in 1 day is assumed to be 2 hours so that $15 \times 2=30$ watts/day. This is the maximum capacity of power that can be generated for 1 day. The power generated minus power used by Smart Greenhouse is 15-91, so there is still a difference of 76 watts/day that can be used, so that a Solar Cell with a capacity of $15 \mathrm{wp}$ is considered safe to use.

(c) Charger controller: The battery used was $12 \mathrm{~V}$, therefore, this charger control will keep the charger voltage $12 \times 10 \%$, the required charger voltage between 13.2-13.4 Volts and when it reaches that voltage, this circuit will automatically stop the battery charging process. Conversely, if the battery voltage drops to 11 Volts, the controller will disconnect so that the battery does not run out. If the battery is $12 \mathrm{~V}, 9 \mathrm{~A}$ and the charger controller is $12 \mathrm{~V}, 10 \mathrm{~A}$, the calculation is $9 \mathrm{~A} / 10 \mathrm{~A}=0.9$ (1 Hour), then charging time of battery is about an hour.

(d) Battery: The power requirements are multiplied 2 times:91x2=182 watt hour $=182 / 12$ volts $/ 9$ amps $=2$ batteries of $9 \mathrm{Ah}$. Battery can serve the needs of 3 days without sunlight: $91 \times 3 \times 2=546$ Watt hour $=546 / 12$ Volt $/ 9 \mathrm{Amp}=5$ batteries of $9 \mathrm{Ah}$. The specification battery was a $65 \mathrm{Ah}$ battery so that it can be used if 7 days without sunlight. With the use of batteries that have stored power: $12 \mathrm{~V}$ x 9A=108 Watts, 108 Watts of load used $108 \mathrm{~W} / 108 \mathrm{~W}=1$ Hour. The ability of a battery that can operate for more than an hour.

(2) Soil moisture sensor testing. Soil moisture sensor testing was performed by applying a voltage to $5 \mathrm{~V}$ sensor. Then the sensor will work by processing analog data and converting it to digital values. The ADC value can be changed in the form of a percentage of soil moisture. According to the sensor readings which have a relationship between voltage $(V)$ and resistance $(\Omega)$ which is inversely proportional. The results of soil moisture sensor can be seen in Figure 6(a). DHT11 sensor testing was performed by giving a voltage of $5 \mathrm{~V}$ DC. Then the sensor will work by processing digital data, the sensor will read the received value and display it to the blynk application namely Temperature and Humidity. The results of DHT11 sensor testing can be seen in Figure 6(b). The blynk application displayed the values of the connected sensors, the DHT11 sensor as room temperature and greenhouse room humidity monitoring, soil moisture sensors for monitoring soil moisture and maintaining the quality of tomato plants. Testing of Blynk on Android can be seen in Figure 6(c). 


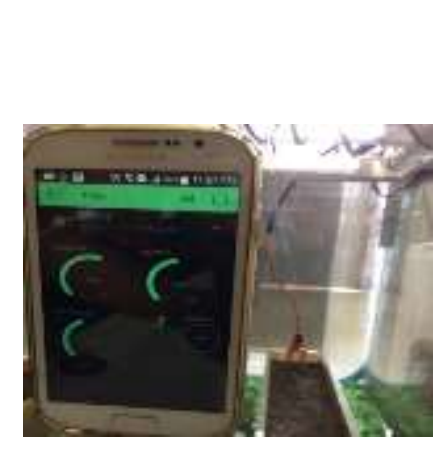

(a)

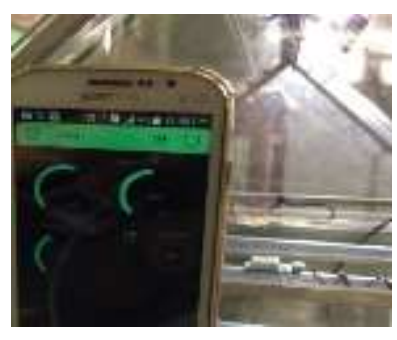

(b)

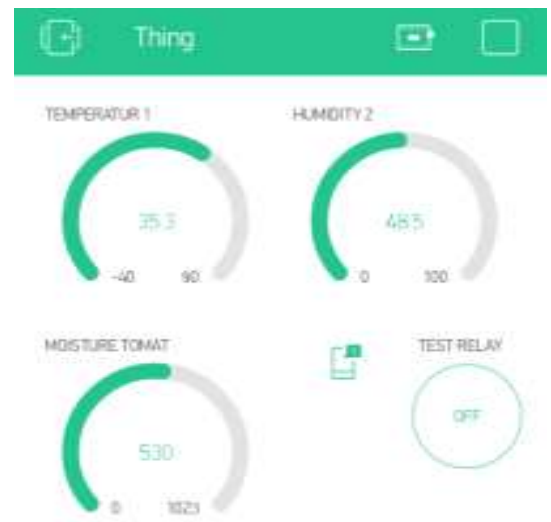

(c)

Figure 6. (a) Soil Moisture Sensor Testing, (b) DHT11 Sensor Testing, and (c) Test result of Blynk Application

\subsection{Feasibility of Learning media}

The operation and maintenance phase was carried out by applying greenhouse media to farmers for one week. Then farmer was given questionnaire to determine the user's response in assessing the feasibility of the media.

a) Feasibility assessment by media expert

The assessment of the developed greenhouse media was assessed by three media experts, namely two from the electrical engineering education lecturers and one from the Faculty of Agriculture lecturer. Experts assessed all aspects of media design, technical and benefits. The following assessment scores by media experts can be seen in Table 5 .

Table 5. Feasibility Score of Media Expert

\begin{tabular}{cccc}
\hline No & Aspect & Mean score & Category \\
\hline 1 & Media design & 4.4 & Very good/very feasible \\
2 & Technical & 4.25 & Very good/very feasible \\
3 & Benefit & 4.4 & Very good/very feasible \\
& Total & 4.35 & Very good/very feasible \\
\hline
\end{tabular}

According to the results of the assessment of three lecturers, the media design had mean score of 4.4 with a very good/very feasible category, on the technical aspect had mean score of 4.25 with a very good/very feasible category, and finally in the aspect of the media benefits had mean score of 4.4 with very good/very feasible. Evaluation of all aspects obtained a mean total score of 4.35 with the category of very good/very feasible.

b) Feasibility assessment by material expert

The assessment of the developed greenhouse media was assessed by three media experts, namely two from the Electrical Engineering lecturers and one from the Faculty of Agriculture lecturer. Experts assessed all aspects, namely material and benefits. The following assessment scores by media experts can be seen in Table 6.

c) Feasibility assessment by user

The test was carried out on farmer's land with the number of respondents of 10 people. In this test there were four aspects of assessment namely media design, technical, material and benefits. The feasibility assessment by the user can be seen in Table 7 .

Table 6. Feasibility Assessment of Material Expert

\begin{tabular}{cccc}
\hline No & Aspect & Mean score & Category \\
\hline 1 & Material & 4.4 & Very good/very feasible \\
2 & Benefit & 4.4 & Very good/very feasible \\
& Total & 4.4 & Very good/very feasible \\
\hline
\end{tabular}


Based on the results of the assessment of three lecturers as material experts, the material aspects had a mean of 4.4 with very good/very feasible category, on the aspect of benefits had a mean of 4.4 with very good/very feasible category. The overall evaluation of aspects had a total score of 4.4 with very good/very feasible.

Table 7. Feasibility assessment by user

\begin{tabular}{cccc} 
& \multicolumn{3}{c}{ Table 7. Feasibility assessment by user } \\
\hline No & Aspect & Mean Score & Category \\
\hline 1 & Media design & 3.95 & Good/feasible \\
2 & Technical & 4.1 & Good/feasible \\
3 & Material & 4.15 & Good/feasible \\
4 & Benefit & 4.05 & Good/feasible \\
& Total & 4.06 & Good/feasible \\
\hline
\end{tabular}

According to the the assessment of users on media, design aspects had a mean of 3.95 with Good/Feasible category, on the technical aspects had a mean of 4.1 with Good/Feasible category, on material aspects had a mean score of 4.15 with Good/Feasible category and on benefit aspect had a mean score of 4.05 with the Good/Feasible category. The overall evaluation of aspects had a total score of 4.06 with the Good/Feasible category. The findings of this research provide insight for feasibility of smart greenhouse for farmers to cultivating tomato plant.

\section{CONCLUSION}

The research objectives to be achieved in this research are developing smart greenhouse as tomato plant cultivation utilizing transparent solar cells as a source of electricity and validate the feasibility of smart greenhouse prototype for farmers. The results showed that a smart greenhouse can perform the growth of tomatoes plant and suitable for cultivating the plants. In order to test the feasibility, the prototype was validated with material expert validators, media expert, and farmers. The level of feasibility in the greenhouse media by media experts in terms of aspects of media design, technical and benefits had a mean score of $\mathrm{X}=4.35$ with the category Very Good/Very Feasible. In the assessment of the manual book by material experts in terms of material aspects and benefits had a value of $\mathrm{X}=4.4$ with the category Very Good/Very Feasible and user assessment in terms of media design, technical, material and benefits had a value of $\mathrm{X}=4.06$ with Good/Feasible category. We believe that our results maybe helpful to further practical development and experiments on the smart greenhouse.

\section{ACKNOWLEDGEMENTS}

The authors would like to thank to the Ministry of Research and Technology/Republic of Indonesia National Research and Innovation Agency, Indonesian Government.

\section{REFERENCES}

[1] Suhariyanto, "Statistic of Horticulture Establishment 2016", BPS-Statistic Indonesia.

[2] D. D. Nangare, Y. Singh, P. S. Kumar, and P. S. Minhas, "Growth, fruit yield and quality of tomato (Lycopersicon esculentum Mill.) as affected by deficit irrigation regulated on phenological basis," Agricultural Water Management, vol. 171, pp. 73-79, Jun. 2016, doi: 10.1016/j.agwat.2016.03.016.

[3] J. Cuartero and R. Fernández-Muñoz, "Tomato and salinity," Scientia Horticulturae, vol. 78, no. 1, pp. 83-125, Nov. 1998, doi: 10.1016/S0304-4238(98)00191-5.

[4] M. Azaza, C. Tanougast, E. Fabrizio, and A. Mami, "Smart greenhouse fuzzy logic based control system enhanced with wireless data monitoring," ISA Transactions, vol. 61, pp. 297-307, Mar. 2016, doi: 10.1016/j.isatra.2015.12.006.

[5] M. A. Zamora-Izquierdo, J. Santa, J. A. Martínez, V. Martínez, and A. F. Skarmeta, "Smart farming IoT platform based on edge and cloud computing," Biosystems Engineering, vol. 177, pp. 4-17, Jan. 2019, doi: 10.1016/j.biosystemseng.2018.10.014.

[6] J. M. Talavera et al., "Review of IoT applications in agro-industrial and environmental fields," Computers and Electronics in Agriculture, vol. 142, pp. 283-297, Nov. 2017, doi: 10.1016/j.compag.2017.09.015.

[7] N. Bennis, J. Duplaix, G. Enéa, M. Haloua, and H. Youlal, "Greenhouse climate modelling and robust control," Computers and Electronics in Agriculture, vol. 61, no. 2, pp. 96-107, May 2008, doi: 10.1016/j.compag.2007.09.014.

[8] D. Karimanzira and T. Rauschenbach, "Enhancing aquaponics management with IoT-based Predictive Analytics for efficient information utilization," Information Processing in Agriculture, vol. 6, no. 3, pp. 375-385, Sep. 2019, doi: 10.1016/j.inpa.2018.12.003. 
[9] M. Srivastava and R. Kumar, "An IoT Based Weather Monitoring System Using Node MCU and Fuzzy Logic," in Second International Conference on Computer Networks and Communication Technologies, Cham, pp. 126-137, 2020, doi: 10.1007/978-3-030-37051-0_14.

[10] W. Yong et al., "Smart Sensors from Ground to Cloud and Web Intelligence," IFAC-PapersOnLine, vol. 51, no. 17, pp. 31-38, Jan. 2018, doi: 10.1016/j.ifacol.2018.08.057.

[11] J. Doshi, T. Patel, and S. kumar Bharti, "Smart Farming using IoT, a solution for optimally monitoring farming conditions," Procedia Computer Science, vol. 160, pp. 746-751, Jan. 2019, doi: 10.1016/j.procs.2019.11.016.

[12] Vij, S. Vijendra, A. Jain, S. Bajaj, A. Bassi, and A. Sharma, "IoT and Machine Learning Approaches for Automation of Farm Irrigation System," Procedia Computer Science, vol. 167, pp. 1250-1257, Jan. 2020, doi: 10.1016/j.procs.2020.03.440.

[13] R. I. S. Pereira, S. C. S. Jucá, and P. C. M. Carvalho, "IoT embedded systems network and sensors signal conditioning applied to decentralized photovoltaic plants," Measurement, vol. 142, pp. 195-212, Aug. 2019, doi: 10.1016/j.measurement.2019.04.085.

[14] A. R. Madushanki, M. N. Halgamuge, W. A. H. S. Wirasagoda, and A. Syed, "Adoption of the Internet of Things (IoT) in Agriculture and Smart Farming towards Urban Greening: A Review," International Journal of Advanced Computer Science and Applications (IJACSA), vol. 10, no. 4, Art. no. 4, 30 2019, doi: 10.14569/IJACSA.2019.0100402.

[15] M. O. Akbar et al., "IoT for Development of Smart Dairy Farming," Journal of Food Quality, Mar. $23,2020$. https://www.hindawi.com/journals/jfq/2020/4242805/ (accessed Jun. 16, 2020).

[16] H. D. Benington, "Production of Large Computer Programs," Annals of the History of Computing, vol. 5, no. 4, pp. 350-361, Oct. 1983, doi: 10.1109/MAHC.1983.10102.

[17] D. F. Walker and R. D. Hess, Instructional software: principles and perspectives for design and use. Belmont, Calif. : Wadsworth Pub. Co., 1984.

[18] L. J. Cronbach, "Coefficient alpha and the internal structure of tests," Psychometrika, vol. 16, no. 3, pp. 297-334, Sep. 1951, doi: 10.1007/BF02310555.

[19] E. P. Widoyoko, "The Evaluation of The Learning Program,” Yogyakarta: Student Library, 2009.

[20] V. P. Mishra, C. Jain, and A. Chugh, "IoT-Based Data Logger for Environmental Monitoring," in Innovations in Computer Science and Engineering: Proceedings of 7th ICICSE, H. S. Saini, R. Sayal, R. Buyya, and G. Aliseri, Eds. Singapore: Springer, pp. 463-471, 2020.

[21] P. Serikul, N. Nakpong, and N. Nakjuatong, "Smart Farm Monitoring via the Blynk IoT Platform: Case Study: Humidity Monitoring and Data Recording," in 2018 16th International Conference on ICT and Knowledge Engineering (ICT KE), Nov. 2018, pp. 1-6, doi: 10.1109/ICTKE.2018.8612441.

[22] D. V. Ploeg and E. Heuvelink, "Influence of sub-optimal temperature on tomato growth and yield: a review," The Journal of Horticultural Science and Biotechnology, vol. 80, no. 6, pp. 652-659, Jan. 2005, doi: 10.1080/14620316.2005.11511994.

[23] S. R. Adams, K. E. Cockshull, and C. R. J. Cave, "Effect of Temperature on the Growth and Development of Tomato Fruits," Annals of Botany, vol. 88, no. 5, pp. 869-877, Nov. 2001, doi: 10.1006/anbo.2001.1524.

[24] W. Yan et al., "Effects of Supplementary Artificial Light on Growth of the Tomato (Solanum lycopersicum) in a Chinese Solar Greenhouse," The Horticulture Journal, vol. 87, no. 4, pp. 516-523, 2018, doi: 10.2503/hortj.OKD165.

[25] J. A. Dieleman, P. H. B. De Visser, E. Meinen, J. G. Grit, and T. A. Dueck, "Integrating Morphological and Physiological Responses of Tomato Plants to Light Quality to the Crop Level by 3D Modeling," Front Plant Sci, vol. 10, Jul. 2019, doi: 10.3389/fpls.2019.00839.

\section{BIOGRAPHIES OF AUTHORS}

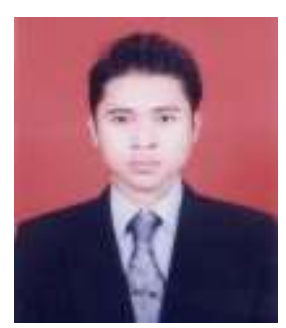

Yus Rama Denny., Ph.D completed his graduate studies with a Ph.D. from the Chungbuk National University in 2014 and his undergraduate studies at the University of Indonesia and Padjadjaran University, Indonesia with a M.Sc dan B.Sc in Physics Material in 2009 and 2006, respectively. In 2009, he joined University of Sultan Ageng Tirtayasa as a researcher and lecturer. He is member of professional association Korean Vacuum Society and American Vacuum Society (a professional Society supports networking among academic, industrial, government, and consulting professionals involved in a variety of disciplines related to materials, interfaces, and processing). He regularly collaborates with the Chungbuk National University (Korea), the University of Southern Denmark (Denmark), and the Pohang Accelerator Laboratory (Korea) among others. He has authored or coauthored over 30 papers published in refereed journals and conferences most of them in Elsevier Publisher and Wiley Online Library. His current research interests are in the areas of X-ray and Electron Spectroscopy, Transparent Conducting Oxide Material, Surface and Interface analysis, include material for biosensor, absorber, antenna and microwave application. 

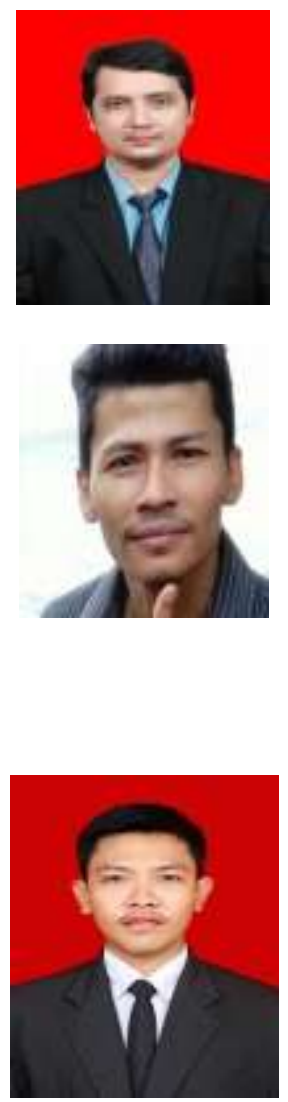

Endi Permata, ST.,MT. completed his undergraduate studies at the Institute Teknologi Sepuluh Nopember and University of Sultan Ageng Tirtayasa, Indonesia with a S.T dan M.T in Electrical Engineering in 2013 and 2003, respectively. In 2005, he joined University of Sultan Ageng Tirtayasa as a researcher and lecturer. His teaching and researching activities in academia cover topics related to Artificial Intelligence, Artificial Neural Network, Image Processing and Computer Architecture.

Adhitya Trenggono, ST, M.Sc was born in Serang, April 10, 1978. Education background: Bachelor of Materials Engineering, FTI ITB (1997-2002), Master in european master in materials science (EMMS) study program at Universidade de Aveiro-Portugal and TUHH Hamburg-Germany with an Erasmus Mundus scholarship (2005-2006). The author has been a Research Fellow at CEA Saclay-France (2007-2009) with a Marie Curie scholarship and at Universite Laval Quebec-Canada (2015) with a Center de Researche du CHU de QuebecUniversite Laval scholarship. The author is a permanent lecturer in the Department of Metallurgical Engineering, FT. Untirta since 2004-present. As a lecturer, the writer is active in scientific publications in reputable National and International Journals, National and International Conferences indexed by Scopus and also in Patents at the national and international levels.

Vaka Gustiono, S.Pd completed his undergraduate studies with an S.Pd. from Sultan Ageng Tirtayasa University, Vocational Education Study Program in Electrical Engineering in 2019. In 2020 he joined SMK Negeri 4 Kota Serang as a teaching teacher/educator. In the field of Electrical Power Installation Engineering and Industrial Electronics Engineering. In 2020, take a master's degree at the Jakarta State Polytechnic, a Masters in Applied Electrical Engineering study program with an interest in Industrial Control Engineering. During undergraduate lectures, he is active in participating in competitions, seminars and workshops, 3rd runner up in the 2016 Cilegon City Level Appropriate Technology Innovation Contest, 1st Place in the National Level Student Work Competition, FKIP Education Festival 2017, Finalists in the National Level Scientific Work and Ideas Contest at the Polytechnic Negeri Malang 2017, Best Video Smart Innovation Of Writing National Writing Competition at Institut Teknologi Sepuluh November 2018. In addition, participating in the Raspberry Pi Workshop in Malang 2018, Internet of Things Workshop in Bandung 2018 and IoT seminar: Challenges and Opportunity of IoT Makers at the University Brawijaya 2018. The work I have made is a prototype of a smart greenhouse using a transparent solar cell as a power plant, a Zelio Smart relay trainer, and a Programmable Logic Controller trainer. 